\title{
Assay of flavonoid aglycones from the species of genus Sideritis (Lamiaceae) from Macedonia with HPLC-UV DAD
}

\author{
BISERA JANESKA ${ }^{1}$ \\ MARINA STEFOVA ${ }^{1 *}$ \\ KALINA ALIPIEVA ${ }^{2}$ \\ ${ }^{1}$ Institute of Chemistry \\ Faculty of Science \\ Sts. Cyril and Methodius University \\ Skopje, Republic of Macedonia \\ 2 Institute of Organic Chemistry with \\ Centre of Phytochemistry \\ Bulgarian Academy of Sciences \\ Sofia, Bulgaria
}

\begin{abstract}
Flavonoids obtained from Sideritis species (Lamiaceae), S. raeseri and S. scardica, grown in Macedonia were studied. Qualitative and quantitative analyses of the flavonoid aglycones were performed using high-performance liquid chromatography (HPLC) with a UV diode array detector. Extracts were prepared by acid hydrolysis in acetone, reextraction in ethyl acetate and evaporation to dryness; the residue dissolved in methanol was subjected to HPLC analysis.

Isoscutellarein, chryseriol and apigenin were identified in the extracts. Also, a 4'-methyl ether derivative of isoscutellarein was found, together with hypolaetin and its methyl ether derivative, which were identified according to previously isolated glycosides and literature data. Quantitation was performed using calibration with apigenin. According to this screening analysis, the samples of the genus Sideritis from Macedonia are rich in polyhydroxy flavones and analogous with the previously studied Mediterranean Sideritis species from the Ibero-North African and Greek Sideritis species with respect to the presence of $8-\mathrm{OH}$ flavones and their derivatives.
\end{abstract}

Keywords: flavonoids, polyhydroxy flavones, Sideritis, HPLC-UV DAD

The genus Sideritis numbers more than 150 species occurring mainly in the Mediterranean area (1). Two species occur in Macedonia (S. scardica Griseb. and S. raeseri). S. scardica is an endemic of the Balkan Peninsula, distributed in Macedonia, Bulgaria, Southwest Albania and Greece. Heywood in Flora Europaea (2) says that S. raeseri and $S$. taurica are synonyms of S. syriaca L., while Baden in Mountain flora of Greece (3) describes $S$. raeseri separately from $S$. syriaca. The populations of $S$. raeseri in Macedonia are located mainly on the Galičica mountain, whereas $S$. scardica is more widespread in the mountains of central and western Macedonia.

* Correspondence, e-mail: marinaiv@iunona.pmf.ukim.edu.mk 
Over the years, the phytochemistry of the genus Sideritis (Lamiaceae) has been studied and various terpenoids, sterols, coumarins, and especially flavonoid aglycones and glycosides have been identified. The flavonoids from Sideritis species grown in the Mediterranean (4-6) and Atlantic regions (7) and North Africa (8) have been extensively studied. The species from the Balkan Peninsula, including several interesting endemic species, have also been studied and found to be rich in phenolic compounds, especially flavonoids, which have been proved to possess a valuable antioxidant activity $(9,10)$. This fact is especially important considering the pharmacological interest and the traditional use of »mountain tea « in folk medicine for its anti-inflammatory and anti-rheumatic properties.

However, data on the chemical composition of the Sideritis species growing in Macedonia are very poor. Hence, identification of the flavonoids in wild growing populations of S. scardica and S. raeseri in this central Balkan region was the aim of our investigation.

\section{EXPERIMENTAL}

Plant material. - Aerial parts of Sideritis raeseri L. (Galičica, Macedonia) and Sideritis scardica L. (Stogovo, Solunska Glava and Karadžica, Macedonia) were collected at flowering in the summer of 2005.

Reagents and authentic samples. - Reagents of HPLC purity were purchased from Sigma Chemical Co. (Germany). Authentic substances: apigenin and chryseriol were the products of Extrasynthese (France), isoscutellarein was kindly donated by Dr. Milena Nikolova of the Institute of Botany, Bulgarian Academy of Sciences, Sofia, Bulgaria. Authentic samples of glycosides of hypolaetin, $3^{\prime}-\mathrm{OCH}_{3}$ hypolaetin and isoscutellarein were previously isolated from Sideritis species and identified in our laboratory using NMR $\left({ }^{1} \mathrm{H}\right.$ and $\left.{ }^{13} \mathrm{C}\right)$ $(11,12)$.

Preparation of plant extracts. - Ground plant material $(0.5 \mathrm{~g})$ was extracted twice with $15 \mathrm{~mL}$ acetone and $1 \mathrm{~mL}$ of concentrated $\mathrm{HCl}$. Extraction was performed in an Erlenmeyer flask with reflux in a water bath for $40 \mathrm{~min}$ at $60^{\circ} \mathrm{C}$. The extract was then cooled, filtered and transferred to a separating funnel. Water $(50 \mathrm{~mL})$ was added and extraction with ethyl acetate was repeated 3 times with $20 \mathrm{~mL}$ each. The ethyl acetate fractions were collected and washed three times with $50 \mathrm{~mL}$ of water each, then dried with anhydrous $\mathrm{Na}_{2} \mathrm{SO}_{4}$, filtered, and evaporated to dryness under low pressure. The residue was dissolved in $1 \mathrm{~mL}$ methanol and the solution was used for analyses of flavonoid aglycones by HPLC.

HPLC analysis. - Flavonoid aglycones in the extracts were identified by the HPLC method, using a Varian HPLC system equipped with a ternary pump Model 9012 and UV diode-array detector Model 9065. A reverse phase column C18 $(250 \times 4.6 \mathrm{~mm}, 5 \mu \mathrm{m}$ particles) was used. The mobile phase consisted of $\mathrm{H}_{2} \mathrm{O}$ with $\mathrm{pH}$ adjusted to 3 with $\mathrm{H}_{3} \mathrm{PO}_{4}$ (A) and $\mathrm{CH}_{3} \mathrm{CN}(\mathrm{B})$, and the elution program for extracts screening was the following: 0-5 $\min 70 \%$ A; $10-20 \min 65 \%$ A; $25-30 \min 55 \%$ A; $40-48 \min 35 \%$ A. The flow rate was $1 \mathrm{~mL} \mathrm{~min}{ }^{-1}$, the temperature was set to $35^{\circ} \mathrm{C}$ and the injection volume was $20 \mu \mathrm{L}$. 
The elution was monitored in the whole UV range and the chromatograms for flavones screening were best seen at $348 \mathrm{~nm}$, which is in the region where flavones exhibit an absorption maximum. Identification was made according to the retention times and UV spectra of the components compared to those of authentic samples of flavonoids.

Quantification of flavones was performed using calibration with standard solutions of apigenin in the range from 0.1 to $1.0 \mathrm{mg} \mathrm{mL}^{-1}$ at $348 \mathrm{~nm}$ (dependence of the peak area vs. concentration of apigenin).

\section{RESULTS AND DISCUSSION}

An HPLC method has been developed for analysis of flavonoids after acid hydrolysis, using a UV diode array detector. Flavone aglycones were identified using authentic substances, UV-spectra and results from our previous research and published data (11-13). The results were compared with the ones published for Sideritis flavonoids in the Balkans and the Mediterranean region. Four samples of wild growing populations (one of S. raeseri and three of $S$. scardica) were studied. Extraction with prior hydrolysis of the glycosides is often used as the first step in studying the profile flavonoid because it enables identification of the flavones present without the need to study the various glycoside forms, which are not readily available as authentic samples.

The chromatograms obtained for the analyzed samples are given in Fig. 1 and the peaks of the identified flavones are numbered from 1 to 6 . The structures of the identified flavones are given in Fig. 2. Identification of the flavones present was performed using authentic samples of isoscutellarein-2, apigenin-4, and chryseriol-6. The 4'-methyl ether of isoscutellarein-5 was identified according to its UV-spectrum and our previous studies of quantitative structure-retention relationships (14), which allow the conclusion that the peak at 19.40 min with a UV-spectrum almost identical to the one of isoscutellarein is due to the presence of its 4'-methyl ether derivative.

Similarly, two peaks at around 5.40 and 9.80 min with almost identical UV-spectra have been identified as due to the presence of hypolaetin- 1 and its methyl ether derivative-3. The position of methylation is probably $3^{\prime}$, which is supported by the data from the isolation and spectroscopic identification of the corresponding glycosides of these flavones (in progress), and also by the literature data (10-13).

The screening results of these extracts relating to the quantity of the aglycones identified are presented in Table 1. From the results shown in Table I, the differences between the two analyzed Sideritis species can be seen with respect to their flavones composition. Hypolaetin and 4'-methyl ether of isoscutellarein were identified only in the S. raeseri extracts, whereas chryseriol was found in all samples of $S$. scardica from different locations. It can also be seen that the total flavonoids content was higher in $S$. raeseri than in the samples of S. scardica.

Extensive chemosystematic studies of the genus Sideritis species using their flavonoid patterns have been performed by Barberan and co-workers $(4,5,8)$. They analyzed the Spanish and north African Sideritis species and found the 8-OH flavones hypolaetin and isoscutellarein to be characteristic and most abundant in the section Sideritis, whereas 5,7-OH flavones were found only in a few studied specimens of Ibero-North African Sideritis. Barberan et al. (8) have broadly divided the species of the genus Sideritis into 


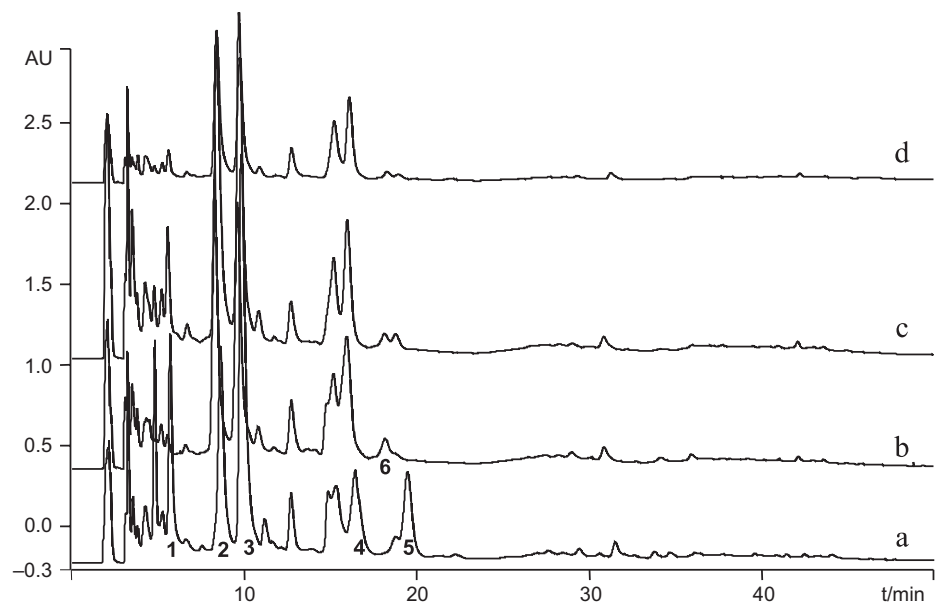

Fig. 1. Chromatograms of extracts of Sideritis species from Macedonia: a) S. raeseri (Galičica), b) S. scardica (Stogovo), c) S. scardica (Solunska Glava), and d) S. scardica (Karadžica) with the flavones identified: 1 - hypolaetin, 2 - isoscutellarein, $3-3^{\prime}-\mathrm{OCH}_{3}$ hypolaetin, 4 - apigenin, 5 - 4'- $\mathrm{OCH}_{3}$ isoscutellarein, and 6 - chryseriol.<smiles>[R]c1ccc(-c2cc(=O)c3c(O)cc(O)c([R])c3o2)cc1[R]</smiles>

\begin{tabular}{clccc}
\hline Compd. No. & & $\mathrm{R}_{1}$ & $\mathrm{R}_{2}$ & $\mathrm{R}_{3}$ \\
\hline 1 & Hypolaetin & $\mathrm{OH}$ & $\mathrm{OH}$ & $\mathrm{OH}$ \\
2 & Isoscutellarein & $\mathrm{OH}$ & $\mathrm{OH}$ & $\mathrm{H}$ \\
3 & $3^{\prime}$-OCH $\mathrm{H}_{3}$ hypolaetin & $\mathrm{OH}$ & $\mathrm{OH}$ & $\mathrm{OCH}_{3}$ \\
4 & Apigenin & $\mathrm{H}$ & $\mathrm{OH}$ & $\mathrm{H}$ \\
5 & $4^{\prime}-\mathrm{OCH}_{3}$ isoscutellarein & $\mathrm{OH}$ & $\mathrm{OCH}_{3}$ & $\mathrm{H}$ \\
6 & chryseriol & $\mathrm{H}$ & $\mathrm{OH}$ & $\mathrm{OCH}_{3}$ \\
\hline
\end{tabular}

Fig. 2. Structures of the flavones identified in the Sideritis species from Macedonia.

two groups based on accumulation of the glycosides of 8-OH flavones and 5,7-OH flavones. In the first group, the 8-OH flavones isoscutellarein and/or hypolaetin are dominant whereas in the section Hesiodia the 5,7-OH flavones chryseriol, luteolin and apigenin are 
B. Janeska et al:: Assay of flavonoid aglycones from the species of genus Sideritis (Lamiaceae) from Macedonia with HPLC-UV DAD, Acta Pharm. 57 (2007) 371-377.

Table I. Content of flavones in the studied Macedonian Sideritis species

\begin{tabular}{|c|c|c|c|c|c|c|}
\hline \multirow{2}{*}{$\begin{array}{l}\text { Plant } \\
\text { material } \\
\text { (location) }\end{array}$} & \multicolumn{6}{|c|}{ Flavones (\% dry mass) } \\
\hline & $\begin{array}{l}\text { Hypo- } \\
\text { laetin }\end{array}$ & $\begin{array}{l}\text { Isoscu- } \\
\text { tellarein }\end{array}$ & $\begin{array}{c}\text { 3'-OCH } \\
\text { hypolaetin }\end{array}$ & Apigenin & $\begin{array}{c}4^{\prime}-\mathrm{OCH}_{3} \\
\text { isoscutellarein }\end{array}$ & Chryseriol \\
\hline S. raeseri (Galičica) & 0.07 & 0.12 & 0.26 & 0.08 & 0.07 & - \\
\hline S. scardica (Stogovo) & - & 0.16 & 0.16 & 0.12 & - & 0.02 \\
\hline $\begin{array}{l}\text { S. scardica } \\
\text { (Solunska Glava) }\end{array}$ & - & 0.19 & 0.20 & 0.10 & - & 0.01 \\
\hline S. scardica (Karadžica) & - & 0.08 & 0.07 & 0.05 & - & traces \\
\hline
\end{tabular}

most abundant. In the studied Macedonian Sideritis samples, the 8-OH flavones are the main flavone compounds in the extracts, but significant amounts of 5,7-OH flavones, notably apigenin, are present as well, which can broadly put them into the first group.

As regards the Balkan Sideritis representatives, the phytochemical studies of Sideritis samples from Bulgaria have revealed the presence of glycosides of isoscutellarein and hypolaetin-4'-methyl ether (9). Studies of Greek S. raeseri (10) have also revealed the presence of 7-O-glycosides of hypolaetin and its $3^{\prime}$ and $4^{\prime}$-methyl ether as well as isoscutellarein and its $4^{\prime}$-methyl ether and their potential antioxidant activity. In our study, the presence of five flavonoid aglycones in S. raeseri has been confirmed. Four of them belong to the group of $8-\mathrm{OH}$ flavones (hypolaetin and isoscutellarein and their methyl ether derivatives).

Comparing the flavone composition of the two studied species of $S$. scardica and $S$. raeseri reveals greater variety of the $8-\mathrm{OH}$ flavones in $\mathrm{S}$. raeseri (hypolaetin; 3'-methyl ether of hypolaetin; isoscutellarein and 4'-methyl ether of isoscutellarein), whereas only isoscutellarein and 3'-methyl ether of hypolaetin were found in S. scardica. Additionally, chryseriol was found only in the $S$. scardica extracts, indicating the possibility of their chemosystematic distinction. These results imply further investigation directed towards testing the possibility of chemosystematic distinguishing between these two Sideritis species based on the presence of 5,7-OH flavones (chryseriol) in Sideritis scardica and 8-OH flavones (hypolaetin, 4'-methyl ether of isoscutellarein) in Sideritis raeseri. These analyses can help in solving the dilemma if $S$. raeseri is a synonym of $S$. syriaca or not, which is still under discussion $(2,3)$.

There are not much data on the quantification of the flavonoid compounds in Sideritis species. Palomino et al. (6) have analyzed the flavonoids content in Spanish Sideritis species using HPLC. They have identified and quantified glycosides of isoscutellarein and hypolaetin, and luteolin, chryseriol and apigenin as aglycons, along with the less polar flavones sideritoflavone, xantomicrol, gardenin D, 8-methoxy cirsilineol and desmetilnobiletine.

This study is the first report on the flavonoids content of the Balkan Sideritis species, which shows their valuable chemical composition and justifies their popular use in the traditional medicine. The species $S$. raeseri has been shown to be richer in variety as well as in quantity of these flavones, ranging from 0.07 to $0.26 \%(\mathrm{~m} / \mathrm{m})$ in dry plant material. The relatively high total content of flavones explains the strong antioxidant activity determined for Sideritis extracts $(9,10)$. 


\section{CONCLUSIONS}

The presence of two types of flavones 8-OH (hypolaetin and isoscutellarein and their methoxy derivatives) and 5,7-OH (apigenin and chryseriol) has been confirmed and the possibility of distinguishing between the two studied species (S. scardica and S. raeseri) is suggested. This hypothesis should be further explored and tested with the Sideritis species from the Balkans in order to establish their chemosystematic distinction. Moreover, the relatively high content of individual polyhydroxy flavones determined in the extracts (up to $0.26 \%$ ) justifies the need for further investigations in order to correlate their biological activities with their chemical composition.

\section{REFERENCES}

1. C. Obon de Castro and D. R. Nunez, Phanerogamarum Monographiae Tomus XXI: A Taxonomic Revision of the Section Sideritis (Genus Sideritis) (Labiatae), J. Cramer, Berlin 1994.

2. V. Heywood, Genus Sideritis L., in Flora Europaea (Eds. T. Tutin, V. Heywood, N. Burges, D. Moore, S. Valentine, S. Walters and D. Webb), Vol. 3, Cambridge University Press, Cambridge 1973, pp. 138-143.

3. C. Baden, Sideritis L., in Mountain Flora of Greece (Ed. A. Strid and K. Tan), Vol. 2, Edinburgh University Press, Edinburgh 1991.

4. F. A. T. Barberan, I. M. Nunez and F. Tomas, An HPLC study of flavones from some Spanish Sideritis species, Phytochemistry 24 (1985) 1285-1288.

5. F. A. T. Barberan, M. I. Gil, F. Ferreres, D. Rivera, C. Obon and F. T. Lorente, Distribution of 8-hydroxyflavone glycosides and flavonoid aglycones in some Spanish Sideritis species, Biochem. Syst. Ecol. 21 (1993) 487-497.

6. O. M. Palomino, P. Gomez-Serranillos, E. Carretero and A. Villar, High-performance liquid chromatography of flavonoids from Sideritis species, J. Chromatogr. A 731 (1996) 103-108.

7. M. I. Gil, F. Ferreres, A. Marrero, F. T. Lorente and F. A. T. Barberan, Distribution of flavonoid aglycones and glycosides in Sideritis species from Canary Islands and Madeira, Phytochemistry 34 (1993) 227-232.

8. F. A. T. Barberan, M. Rejdali, J. B. Harborne and H. Heywood, External and vacuolar flavonoids from Ibero-North African Sideritis Species. A chemosystematic approach, Phytochemistry 27 (1988) 165-170.

9. I. I. Koleva, J. P. H. Linssen, T. A. van Beek, Lj. B. Evstatieva, V. Kortenska and N. Handjieva, Antioxidant activity of extracts from Sideritis species (Labiatae) grown in Bulgaria, J. Sci. Food Agric. 83 (2003) 809-819; DOI: 10.1002/jsfa.1415.

10. C. N. Gabrieli, P. G. Kefalas and E. L. Kokkalou, Antioxidant activity of flavonoids from Sideritis raeseri, J. Ethnopharmacol. 96 (2005) 423-428; DOI: 10.1016/j.jep.2004.09.031.

11. A. A. Sattar, V. Bankova, S. Spassov and H. Duddek, Flavonoid glycosides from Sideritis species, Fitoterapia 64 (1993) 278-279.

12. A. A. Sattar, Flavonoids and Terpenoids in Some Representatives of Lamiaceae Family, PhD Thesis, Institute of Organic Chemistry with Centre of Phytochemistry, Bulgarian Academy of Sciences, Sofia 1994.

13. A. Lenherr, B. Meier and O. Sticher, Modern HPLC as a tool for chemotaxonomical investigations: iridoid glucosides and acetylated flavonoids in the group of Stachys recta, Planta Medica 1984, 365-458. 
B. Janeska et al:: Assay of flavonoid aglycones from the species of genus Sideritis (Lamiaceae) from Macedonia with HPLC-UV DAD, Acta Pharm. 57 (2007) 371-377.

14. M. Stefova, T. Stafilov, S. Kulevanova, G. Stefkov and V. S. Bankova, QSRR of flavones-evaluation of substituent contribution to RP HPLC retention, J. Liq. Chromatogr. Rel. Technol. 30 (2007) 1035-1049; DOI: 10.1080/10826070601128402.

\section{$S A \check{Z} E T A K$}

\section{Određivanje aglikona flavonoida iz vrsta roda Sideritis (Lamiaceae) iz Makedonije pomoću HPLC-UV DAD}

BISERA JANESKA, MARINA STEFOVA i KALINA ALIPIEVA

U radu su proučavani flavonoidi dobiveni iz vrsta Sideritis (Lamiaceae), S. raeseri i S. scardica, podrijetlom iz Makedonije. Kvalitativna i kvantitativna analiza aglikona flavonoida provedena je pomoću tekućinske kromatografije visoke učinkovitosti (HPLC) s UV detektorom. Ekstrakti su pripravljeni kiselom hidrolizom u acetonu, te ponovnom ekstrakcijom etil-acetatom. Ostatak nakon uparavanja je otopljen u metanolu i analiziran pomoću HPLC.

Usporedbom s ranije izoliranim glikozidima i s literaturnim podacima u ekstraktima su identifirani izoskutelarein, krizeriol, apigenin, 4'-metil eterski derivat izoskutelareina, hipolaetin te njegov metil eter. Kvantifikacija je provedena pomoću kalibracijske krivulje za apigenin.

Rezultati ukazuju da su uzorci Sideritis roda iz Makedonije bogati polihidroksiflavonima kao i ranije proučavane mediteranske vrste Sideritis iz sjeverne Afrike i iz Grčke.

Ključne riječi: flavonoidi, polihidroksiflavoni, Sideritis, HPLC-UV DAD

Institute of Chemistry, Faculty of Science, Sts. Cyril and Methodius University, Skopje Republic of Macedonia

Institute of Organic Chemistry with Centre of Phytochemistry, Bulgarian Academy of Sciences Sofia, Bulgaria 